\title{
Pengembangan Media Pembelajaran Variasi Permainan Bola Voli Berbasis Aplikasi Articulate Storyline
}

\author{
Ari Hakiim Putra*, Ari Wibowo Kurniawan, Mu'arifin \\ Universitas Negeri Malang, Jl. Semarang No. 5 Malang, Jawa Timur, Indonesia \\ *Penulis korespondensi, Surel: arihakiimputra@gmail.com
}

Paper received: 17-6-2021; revised: 1-7-2021; accepted: 8-7-2021

\begin{abstract}
This research and development aims to develop application learning media about variations of volleyball games for the KKG PJOK Elementary Schools in Senduro District, Lumajang Regency. The method used is the Research and Development approach with a development research model with the steps (1) needs analysis, (2) doing product design (design), (3) product development (development), (4) implementation or (implementation), and (5) product evaluation (evaluation). The results of the whole product trial involved 22 teachers of KKG PJOK, Senduro District, Lumajang Regency. The results of the study showed the product was included in the very valid category with a percentage of 80.2 percent in small group trials with 8 activity participants and 80 percent in large group trials with 14 activity participants. So it is concluded that the product development of learning media variations of volleyball games based on the articulate storyline application has very valid criteria and is suitable for use in learning activities.
\end{abstract}

Keywords: media; volleyball; games; articulate storyline

\begin{abstract}
Abstrak
Penelitian dan pengembangan ini bertujuan untuk mengembangkan media pembelajaran aplikasi tentang variasi permainan bola voli untuk KKG PJOK Sekolah Dasar di Kecamatan Senduro Kabupaten Lumajang. Metode yang digunakan yaitu pendekatan Research and Development dengan model penelitian pengembangan dengan langkah-langkah (1) Analisis kebutuhan (analysis), (2) melakukan desain produk (design), (3) pengembangan produk (development), (4) pelaksanaan atau (implementation), dan (5) evaluasi produk (evaluation). Hasil uji coba keseluruhan produk melibatkan 22 guru KKG PJOK Kecamatan Senduro Kabupaten Lumajang. Hasil dari penelitian menunjukan produk termasuk dalam kategori sangat valid dengan hasil persentase 80,2 persen pada uji coba kelompok kecil dengan jumlah 8 peserta kegiatan dan persentase 80 persen pada uji coba kelompok besar dengan jumlah 14 peserta kegiatan. Sehingga disimpulkan bahwa produk pengembangan media pembelajaran variasi permainan bola voli berbasis aplikasi articulate storyline memiliki kriteria sangat valid serta layak dipakai pada kegiatan pembelajaran.
\end{abstract}

Kata kunci: media; bola voli; permainan; articulate storyline

\section{Pendahuluan}

Kemajuan teknologi dalam dunia pendidikan saat ini salah satunya adalah guru, guru berperan aktif dalam memajukan dunia pendidikan, pembaharuan sistem pembelajaran sangat bergantung kepada guru. Di Era kemajuan teknologi saat ini guru diharuskan memiliki kemampuan dalam menguasai bidang teknologi, karena guru dituntut semaksimal mungkin dapat mengelola kelas secara baik dan efisien, guru yang menguasai teknologi dan dapat mengelola kelas secara baik secara tidak langsung sudah berperan dalam memajukan dunia pendidikan di era saat ini. Pemerintah sudah berupaya dalam memajukan dunia pendidikan dengan membentuk calon guru yang memiliki mutu dan profesionalisme untuk menjadi seorang guru, hal ini berbanding terbalik dengan guru-guru yang sudah lama mengabdi sebelum teknologi berkembang pesat, sehingga banyak sekali guru yang kurang paham bahkan 
tidak paham akan teknologi yang dapat dimanfaatkan pada saat proses pembelajaran. Guruguru muda yang harus menguasai teknologi dan membantu guru senior untuk memahami kemajuan teknologi khususnya dibidang pendidikan.

Pendidikan jasmani adalah mata pelajaran yang dalam proses pembelajarannya mengutamakan aktivitas fisik, keterampilan gerak yang bertujuan untuk mengembangkan kemampuan intelektual, sikap, dan psikomotorik pada siswa yang dilaksanakan di setiap jenjang pendidikan (Bangun 2016). Pendidikan jasmani adalah pelajaran yang telah disusun secara terstruktur, terarah serta terencana melalui kegiatan pembelajaran yang terdapat, afektif, kognitif dan psikomotorik dengan tujuan mengembangkan pengetahuan dan keterampilan peserta didik secara keseluruhan. Pendidikan jasmani adalah sebuah proses untuk meningkatkan kemampuan psikomotorik, afektif, dan kognitif melalui aktivitas jasmani (Rahayu, 2014).

Tabel 1. Kompetensi Inti \& Kompetensi Dasar Pendidikan Jasmani dan Kesehatan Kelas VI

\begin{tabular}{|c|c|}
\hline Kompetensi Dasar Pengetahuan Kelas VI & Kompetensi Dasar Keterampilan Kelas VI \\
\hline $\begin{array}{l}\text { 3. Memahami pengetahuan faktual dengan cara } \\
\text { mengamati dan menanya berdasarkan rasa ingin tahu } \\
\text { tentang dirinya, makhluk ciptaan Tuhan dan kegiatanya, } \\
\text { dan benda-benda yang dijumpai di rumah, di sekolah } \\
\text { dan tempat bermain. }\end{array}$ & $\begin{array}{l}\text { 4. menyajikan pengetahuan faktual dalam } \\
\text { bahasa yang jelas, sistematis dan logis, dalam } \\
\text { karya yang estetis, dalam gerakan yang } \\
\text { mencerminkan perilaku anak bermain dan } \\
\text { berakhlak mulia. }\end{array}$ \\
\hline Kompetensi Dasar Pengetahuan Kelas VI & Kompetensi Dasar Keterampilan Kelas VI \\
\hline $\begin{array}{l}3.1 \text { Memahami variasi gerak dasar lokomotor, non- } \\
\text { lokomotor, dan manipulatif sesuai dengan konsep tubuh, } \\
\text { ruang, usaha, dan keterhubungan dalam permainan bola } \\
\text { besar sederhana dan atau tradisional. }\end{array}$ & $\begin{array}{l}\text { 4.1 Mempraktikkan variasi gerak dasar } \\
\text { lokomotor, non-lokomotor, dan manipulatif } \\
\text { sesuai dengan konsep tubuh, ruang, usaha dan } \\
\text { keterhubungan dalam permainan bola besar } \\
\text { sederhana dan atau tradisional. }\end{array}$ \\
\hline
\end{tabular}

Sumber: Permendikbud 2018.

Dari tabel yang telah dipaparkan dapat digunakan untuk membuat dan bahkan mengembangkan media pembelajaran materi variasi permainan bola voli yang lebih menarik sehingga menumbuhkan suasana baru kepada peserta didik. Bola voli adalah salah satu olahraga yang sering dimainkan oleh kedua kelompok yang saling berlawanan dan dibatasi oleh net, setiap kelompoknya terdiri dari 6 orang pemain. Yusmar (2017) mengatakan bahwa bola voli adalah olahraga permainan yang dimainkan oleh dua grup yang saling berlawanan. Setiap grup memiliki enam orang pemain. Setiap kelompok yang terdiri dari 6 orang pemain ini saling berusaha untuk menjatuhkan bola didaerah lawan sehingga mendapatkan poin. Bola Voli mini menjadi salah satu alternatif yang dapat diberikan oleh anak Sekolah Dasar karena hampir menyerupai permainan bola voli sebenarnya, mengingat keterampilan gerak dasar fundamental siswa Sekolah Dasar yang masih kurang.

Pembelajaran dapat dimaknai sebagai proses penambahan pengetahuan dan wawasan melalui rangkaian aktivitas yang dilakukan secara sadar oleh seseorang sehingga terjadi perubahan yang sifatnya positif pada dirinya, dan pada tahap akhir akan mendapatkan keterampilan, kecakapan dan pengetahuan yang baru. Proses pembelajaran pada era teknologi berkembang pesat saat ini, guru bukan hanya satu-satunya acuan dalam menyampaikan materi pembelajaran terhadap peserta didik, namun siswa harus bisa berperan aktif dalam mencari materi dan menyampaikannya kepada peserta didik lainya. Pembelajaran merupakan kegiatan belajar yang antara lain dilakukan oleh guru dalam mengkondisikan seseorang untuk belajar, 
proses interaksi antara guru dengan peserta didik baik interaksi secara langsung seperti kegiatan tatap muka maupun secara tidak langsung atau online, yaitu dengan menggunakan berbagai media pembelajaran yang menarik untuk peserta didik (Asmadawati, 2014).

Media merupakan segala sesuatu yang digunakan untuk menyalurkan informasi atau materi dalam segalah bentuk kegiatan. Media pembelajaran adalah segala sesuatu yang dapat menyalurkan pesan yang dapat merangsang pikiran, perasaan, dan kemauan peserta didik sehingga dapat mendorong terciptanya proses belajar pada diri peserta didik (Ekayani, 2017). Media sebagai segala bentuk dan saluran yang digunakan untuk menyampaikan pesan atau informasi agar bisa diterima oleh penerima. Manfaat media pembelajaran menurut (Dwijayani, 2019) ada dua, pertama, sebagai pedoman bagi guru untuk mencapai tujuan pembelajaran dan dapat menjelaskan materi pembelajaran dengan urutan yang sistematis dan penyajian yang menarik, kedua, dapat meningkatkan motivasi dan minat belajar peserta didik sehingga peserta didik dapat berfikir dan menganalisis materi yang diberikan oleh guru dengan baik dalam situasi pembelajaran yang menyenangkan. Isi dari media tersebut adalah materi yang disampaikan kepada peserta didik dengan mengacu kepada KD Kemudian RPP dan Silabus sehingga materi yang disampaikan sesuai dengan pedoman pendidikan di Indonesia. Setelah bahan ajar tersampaikan kepada siswa, guru memberikan ujian atau evaluasi yang tujuannya agar melihat seberapa paham siswa terhadap pembelajaran yang disampaikan. Evaluasi adalah salah satu faktor penting untuk efektivitas pembelajaran sebagai pendorong peserta didik untuk lebih giat belajar secara berkelanjutan dan mendorong guru untuk lebih meningkatkan kualitas proses pembelajaran (Widoyoko, 2013).

Dunia pendidikan terus berbenah mengikuti perkembangan zaman, pada zaman saat ini teknologi berkembang sangat pesat di berbagai bidang salah satunya bidang pendidikan. Bahan ajar dan bahkan evaluasi pembelajaran telah banyak menggunakan media aplikasi sebagai penyampaian materi. Sehingga di era teknologi saat ini perangkat pembelajaran sebisa mungkin dapat diperbaharui yang dulu hanya berupa print out sekarang harus bisa dalam bentuk aplikasi agar memudahkan guru dan siswa. Media sangat diperlukan dalam menunjang proses pembelajaran di Indonesia. Puspitasari dkk (2018) media pembelajaran merupakan salah satu alat untuk mencapai tujuan pembelajaran. Yaitu dengan memanfaatkan media sebagai alat untuk menyampaikan pesan ataupun informasi yang dikemas secara menarik sehingga dapat tercapai tujuan pembelajaran. Guru sekarang tidak hanya selalu menyampaikan bahan ajar secara ceramah dan tatap muka, akan tetapi sekarang guru dapat menyampaikan pembelajaran secara jarak jauh dan dimana saja. Zaman sekarang telah banyak media pembelajaran yang dapat guru gunakan, seperti Articulate storyline aplikasi yang dapat membuat media pembelajaran dalam bentuk html5, android, flv dan link. Cara penggunaan yang sangat mudah dimengerti menggabungkan gambar, animasi, suara dan video dalam satu media yang dijalankan. Articulate storyline merupakan perangkat lunak (software) yang digunakan sebagai alat komunikasi atau media presentasi dengan template yang dapat dibuat sendiri atau bahkan dapat membuat presentasi dengan template yang telah disediakan dan dapat menyajikan sesuai dengan selera (Rafmana dkk, 2018). Media ini sangat bermanfaat untuk membantu guru dalam proses pembelajaran, namun tidak semua guru dapat mengoperasikan media ini sehingga diperlukan kerja sama antar guru. Kelompok Kerja Guru (KKG) adalah suatu tempat perkumpulan guru-guru sesuai dengan bidangnya masing-masing, di setiap Kecamatan bahkan Kabupaten pasti memiliki perkumpulan atau forum. Kelompok Kerja Guru (KKG) adalah tempat yang sangat ideal bagi guru untuk peningkatan kinerja guru 
seperti melalui berbagai pelatihan, meningkatkan sarana dan prasarana, dan peningkatan mutu manajemen KKG (Nur, 2017).

Sehingga pelaksanaan pembelajaran harus mengikuti perkembangan zaman, supaya proses pembelajaran sesuai dengan karakter peserta didik. Penelitian sebelumnya Saputra dan Agustina (2014) menyatakan bahwa dengan adanya media pembelajaran interaktif dapat lebih memaksimalkan siswa dalam belajar teknik dasar, sekolahan dan guru dapat terbantu sehingga lebih mudah dalam menyampaikan pembelajaran ke siswa Sekolah Dasar, dengan ini juga dapat memaksimalkan siswa dalam bermain bola voli.

Hasil analisis kebutuhan sebagai observasi awal dengan cara mewawancarai ketua KKG, dan juga membagikan angket melalui ketua dan sekretaris KKG berbentuk google form yang selanjutnya disebarkan ke grup whatsapp KKG PJOK SD Se-Kecamatan Senduro Kabupaten Lumajang. Diperoleh data 100\% guru pernah memberikan materi bola voli kepada peserta didik, 100\% guru mengajarkan materi bola voli melalui permainan, 68,2\% guru melakukan pembelajaran secara daring kepada peserta didik selama pandemic covid-19, 86,4\% guru tidak mengetahui tentang pembelajaran melalui aplikasi articulate storyline. Dari latar belakang tersebut, peneliti mengambil langkah untuk penelitian dan pengembangan yang berjudul "Pengembangan Media Pembelajaran Variasi Permainan Bola Voli Berbasis Aplikasi Articulate Storyline untuk Kelompok Kerja Guru (KKG) PJOK Sekolah Dasar di Kecamatan Senduro Kabupaten Lumajang".

\section{Metode}

Penelitian Pengembangan media pembelajaran aplikasi tentang variasi permainan bola voli untuk KKG PJOK Sekolah Dasar Kelas IV di Kecamatan Senduro Kabupaten Lumajang menggunakan penelitian kualitatif dan kuantitatif. Model pengembangan yang digunakan dalam penelitian dan pengembangan media pembelajaran ini adalah model Lee \& Owens, (2004) yang terdiri dari Analisis kebutuhan (analysis), melakukan desain produk (design), pengembangan produk (development), pelaksanaan atau (implementation), dan evaluasi produk (evaluation). Untuk mendapatkan suatu data penelitian dan informasi pendekatan kuantitatif dengan menggunakan data angket. Jenis data penelitian adalah data primer dan sekunder.

Instrumen yang digunakan dalam penelitian dan pengembangan media pembelajaran aplikasi tentang variasi permainan bola voli untuk KKG PJOK sekolah dasar kelas IV Kecamatan Senduro Kabupaten Lumajang adalah observasi awal menggunakan angket untuk analisis kebutuhan, angket untuk mengetahui hasil uji coba kelompok kecil dan uji coba kelompok besar, serta angket untuk para ahli yaitu dari ahli pembelajaran, ahli media, ahli permainan, ahli PJOK, dan ahli bola voli.

Teknik analisis data yang telah digunakan dalam penelitian dan pengembangan media pembelajaran aplikasi tentang variasi permainan bola voli untuk KKG PJOK sekolah dasar kelas IV Kecamatan Senduro Kabupaten Lumajang menggunakan skala likert. Skala Likert ini berfungsi untuk menganalisis sikap, pendapat dan persepsi dari seseorang mengenai fenomena sosial, fenomena sosial ini disebut sebagai variabel penelitian. Variabel yang akan diukur kemudian dijabarkan menjadi indikator variabel, kemudian indikator tersebut digunakan sebagai tolak ukur dalam penyusunan instrumen berupa pertanyaan-pertanyaan. Jawaban dari pertanyaan skala Likert ini mempunyai tingkatan dari sangat positif sampai 
sangat negatif, untuk jawaban akan diberi skor, (4) sangat setuju, (3) setuju, (2) ragu-ragu, dan (1) tidak setuju (Sugiyono, 2015).

Tabel 2. Skala Penilaian Pernyataan Positif

\begin{tabular}{clccc}
\cline { 2 - 4 } No. & Keterangan & Jawaban & Skor Positif \\
\hline 1. & Sangat Setuju & A & 4 \\
2. & Setuju & B & 3 \\
3. & Ragu-ragu & C & 2 \\
4. & Tidak Setuju & D & 1 \\
\hline
\end{tabular}

(Sumber: Sugiyono, 2015:135)

Rumus yang digunakan dalam mengolah data dalam bentuk analisis deskriptif kuantitatif persentase, sebagai berikut:

$V=\frac{T S E V}{S-\max } \times 100 \%$

Keterangan:

$\mathrm{V} \quad$ : Validitas

TSEV : Total skor empirik validator

S-max : Skor maksimal yang diharapkan

100\% : Bilangan konstanta

Selanjutnya agar memudahkan pada perolehan ketepatan data hasil analisis persentase, maka diklasifikasikan dengan rentangan persentase perolehan yang didapatkan. Menurut (Irawan \& Japarianto, 2013) dalam jurnalnya, klasifikasi persentase berikut ini:

Tabel 3. Kriteria dan Parameter Kualitas Produk

\begin{tabular}{clc}
\hline Kriteria & Keterangan & Makna \\
\hline $75,01 \%-100,00 \%$ & Sangat Valid & Digunakan tanpa revisi \\
$50,01 \%-75,00 \%$ & Cukup Valid & Digunakan dengan revisi kecil \\
$25,01 \%-50,00 \%$ & Tidak Valid & Tidak dapat digunakan \\
$00,00 \%-25,00 \%$ & Sangat Tidak Valid & Terlarang digunakan \\
\hline : Irawan \& Japarianto, 2013) &
\end{tabular}

(Sumber: Irawan \& Japarianto, 2013)

\section{Hasil dan Pembahasan}

\subsection{Hasil}

Data yang dipaparkan pada bahasan ini meliputi data: 1) validasi ahli Pembelajaran, 2) validasi ahli Media, 3) validasi ahli permainan, 4) validasi ahli PJOK, 5) validasi ahli bola voli, 6) uji coba kelompok kecil, 7) uji coba kelompok besar. 
Tabel 4. Hasil Analisis Data Ahli Pembelajaran

\begin{tabular}{clcc}
\hline No & Aspek & Kelayakan & Kategori \\
\hline 1 & Kesesuaian & $75 \%$ & Cukup Valid \\
2 & Kejelasan & $72 \%$ & Cukup Valid \\
3 & Kemudahan & $75 \%$ & Cukup Valid \\
4 & Ketepatan & $75 \%$ & Cukup Valid \\
5 & Keefektifan & $75 \%$ & Cukup Valid \\
\hline \multicolumn{2}{l}{ Rata-rata } & $74.4 \%$ & Cukup Valid \\
\hline
\end{tabular}

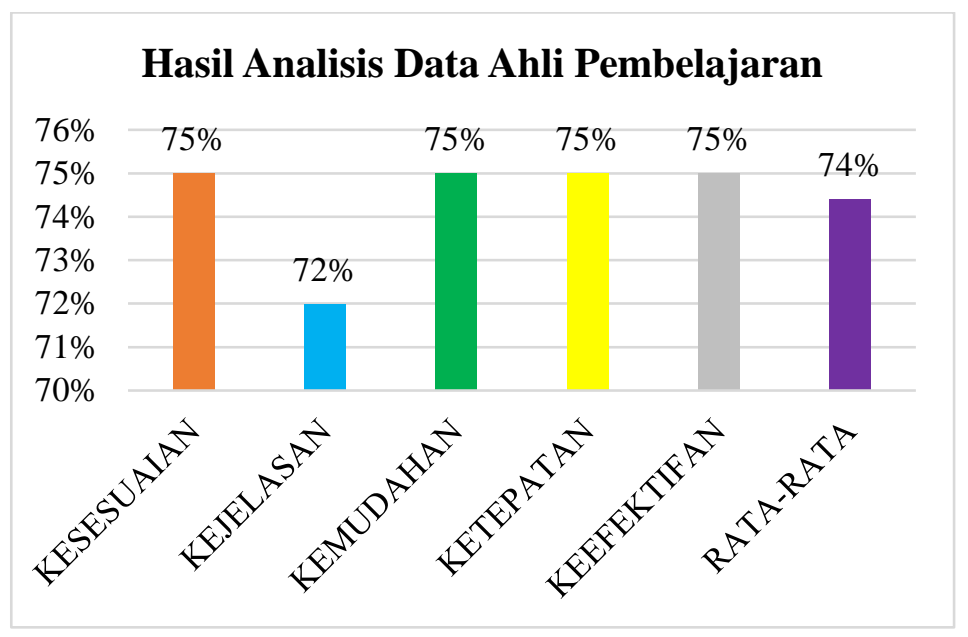

\section{Gambar 1. Diagram Persentase Penilaian Ahli Pembelajaran pada Produk Pengembangan} Media Pembelajaran Aplikasi Variasi Permainan Bola Voli

Dari hasil analisis data yang diperoleh dari ahli pembelajaran dengan persentase sebesar $74 \%$, hasil tersebut didapatkan berdasarkan aspek-aspek tertentu kemudian dikonversikan berdasarkan tabel klasifikasi kelayakan menunjukan bahwa produk pengembangan media pembelajaran variasi permainan bola voli telah memenuhi kriteria cukup valid dan layak digunakan.

Tabel 5. Hasil Analisis Data Ahli Media

\begin{tabular}{cccc}
\hline No & Aspek & Kelayakan & Kategori \\
\hline 1 & Ketepatan & $100 \%$ & Sangat Valid \\
2 & Kemenarikan & $93 \%$ & Sangat Valid \\
3 & Kesesuaian & $100 \%$ & Sangat Valid \\
4 & Kemudahan & $87.5 \%$ & Sangat Valid \\
\hline Rata-rata & $95 \%$ & Sangat Valid \\
\hline
\end{tabular}




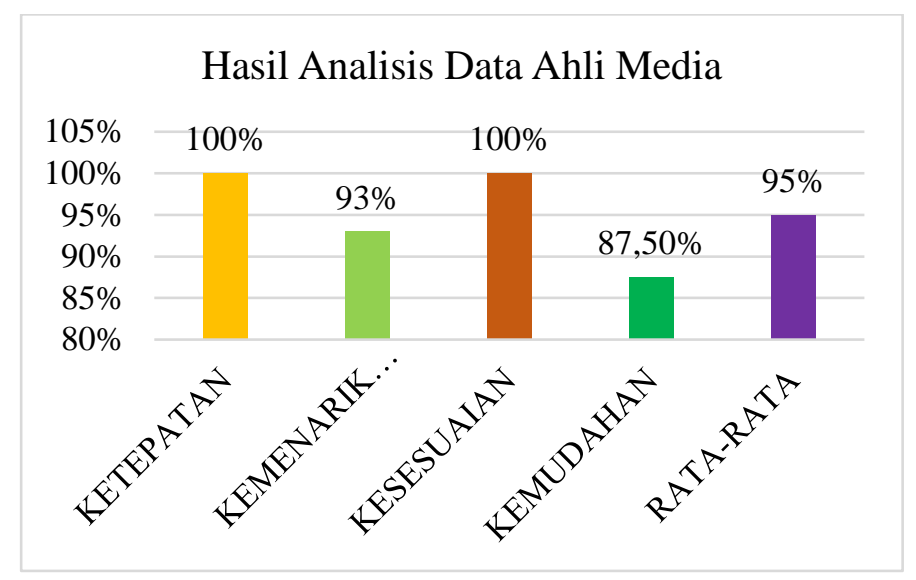

Gambar 2. Diagram Persentase Penilaian Ahli Media pada Produk Pengembangan Media Pembelajaran Aplikasi Variasi Permainan Bola voli

Dari hasil analisis data yang diperoleh dari ahli media dengan persentase sebesar 95\%, hasil tersebut didapatkan berdasarkan aspek-aspek tertentu kemudian dikonversikan berdasarkan tabel klasifikasi kelayakan menunjukan bahwa produk pengembangan media pembelajaran variasi permainan bola voli telah memenuhi kriteria sangat valid dan layak digunakan.

Tabel 6 Hasil Analisis Data Ahli Permainan

\begin{tabular}{clcl}
\hline No & Aspek & Kelayakan & Kategori \\
\hline 1 & Kesesuaian & $95 \%$ & Sangat Valid \\
2 & Kemampuan & $100 \%$ & Sangat Valid \\
3 & Kejelasan & $95 \%$ & Sangat Valid \\
4 & Kemenarikan & $97 \%$ & Sangat Valid \\
\hline Rata-rata & $97 \%$ & Sangat Valid \\
\hline
\end{tabular}

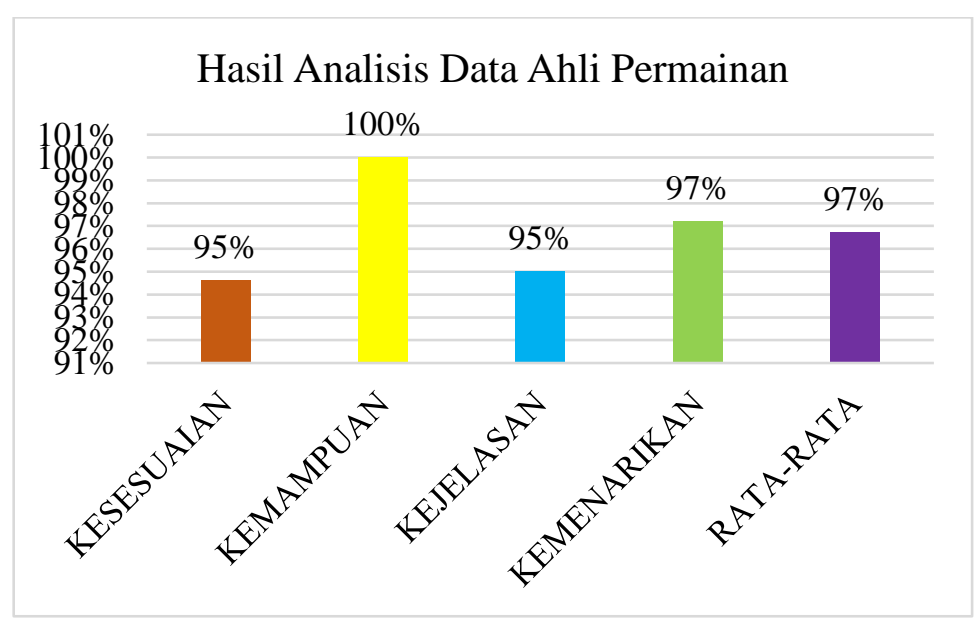

\section{Gambar 3. Diagram Persentase Penilaian Ahli Permainan pada Produk Pengembangan Media Pembelajaran Aplikasi Variasi Permainan Bola Voli}

Dari hasil analisis data yang diperoleh dari ahli permainan dengan persentase sebesar 97\%, hasil tersebut didapatkan berdasarkan aspek-aspek tertentu kemudian dikonversikan berdasarkan tabel klasifikasi kelayakan menunjukan bahwa produk pengembangan media 
pembelajaran variasi permainan bola voli telah memenuhi kriteria sangat valid dan layak digunakan.

Tabel 7. Hasil Analisis Data Ahli PJOK

\begin{tabular}{cccc}
\hline No & Aspek & Kelayakan & Kategori \\
\hline 1 & Kesesuaian & $75 \%$ & Cukup Valid \\
2 & Kejelasan & $75 \%$ & Cukup Valid \\
3 & Kemudahan & $75 \%$ & Cukup Valid \\
4 & Ketepatan & $75 \%$ & Cukup Valid \\
5 & Keefektifan & $75 \%$ & Cukup Valid \\
\hline Rata-rata & $75 \%$ & Cukup Valid \\
\hline
\end{tabular}

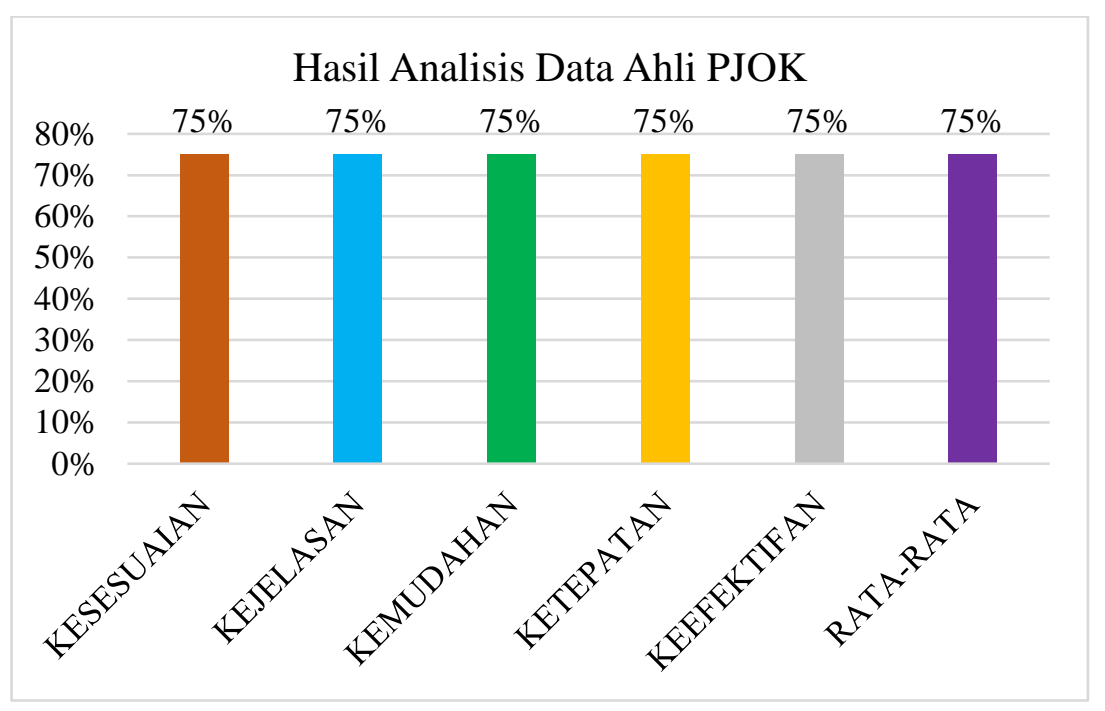

\section{Gambar 4. Diagram Persentase Penilaian Ahli PJOK pada Produk Pengembangan Media Pembelajaran Aplikasi Variasi Permainan Bola Voli}

Dari hasil analisis data yang diperoleh dari ahli PJOK dengan persentase sebesar 75\%, hasil tersebut didapatkan berdasarkan aspek-aspek tertentu kemudian dikonversikan berdasarkan tabel klasifikasi kelayakan menunjukan bahwa produk pengembangan media pembelajaran variasi permainan bola voli telah memenuhi kriteria cukup valid dan layak digunakan.

Tabel 8. Hasil Analisis Data Ahli Bola Voli

\begin{tabular}{cccc}
\hline No & Aspek & Kelayakan & Kategori \\
\hline 1 & Kejelasan & $81.8 \%$ & Sangat Valid \\
2 & Ketepatan & $87.5 \%$ & Sangat Valid \\
3 & Kemenarikan & $90 \%$ & Sangat Valid \\
\hline Rata-rata & $86.4 \%$ & Sangat Valid \\
\hline
\end{tabular}




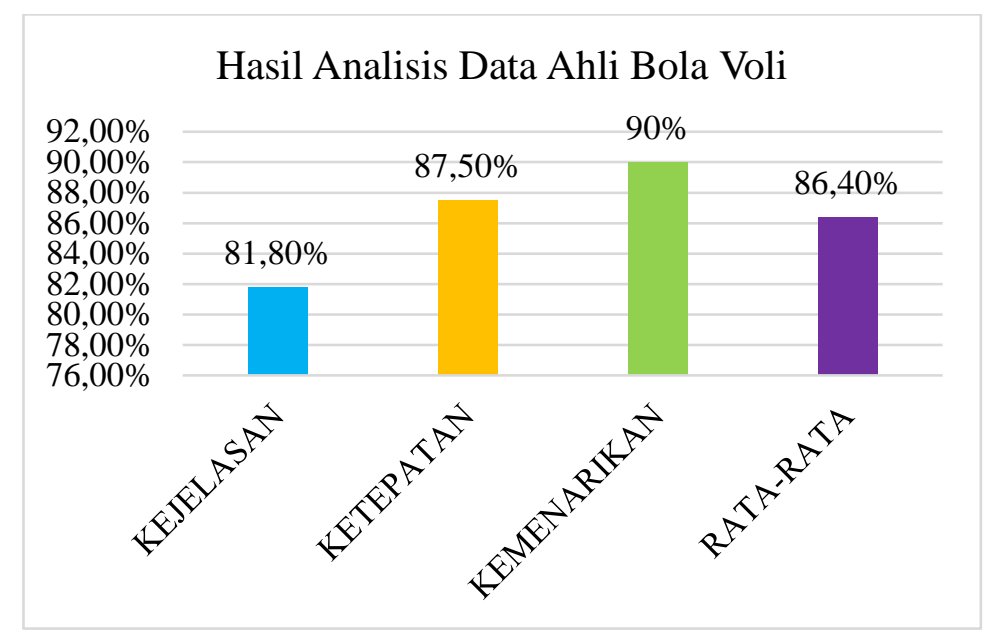

\section{Gambar 5. Diagram Persentase Penilaian Ahli Bola voli pada Produk Pengembangan Media Pembelajaran Aplikasi Variasi Permainan Bola Voli}

Dari hasil analisis data yang diperoleh dari ahli Bola voli dengan persentase sebesar 86.4\%, hasil tersebut didapatkan berdasarkan aspek-aspek tertentu kemudian dikonversikan berdasarkan tabel klasifikasi kelayakan menunjukan bahwa produk pengembangan media pembelajaran variasi permainan bola voli telah memenuhi kriteria sangat valid dan layak digunakan.

Tabel 9. Hasil Analisis Data Uji Coba Kelompok Kecil Pada Kelompok Kerja Guru (KKG) PJOK Sekolah Dasar

\begin{tabular}{cccc}
\hline No & Aspek & Kelayakan & Kategori \\
\hline 1 & Kemenarikan & $80.70 \%$ & Sangat Valid \\
2 & Ketepatan & $82.50 \%$ & Sangat Valid \\
3 & Kesesuaian & $79.60 \%$ & Sangat Valid \\
4 & Kejelasan & $91 . \%$ & Sangat Valid \\
5 & Kemudahan & $71.88 \%$ & Cukup Valid \\
\hline Rata-rata & $81.50 \%$ & Sangat Valid \\
\hline
\end{tabular}

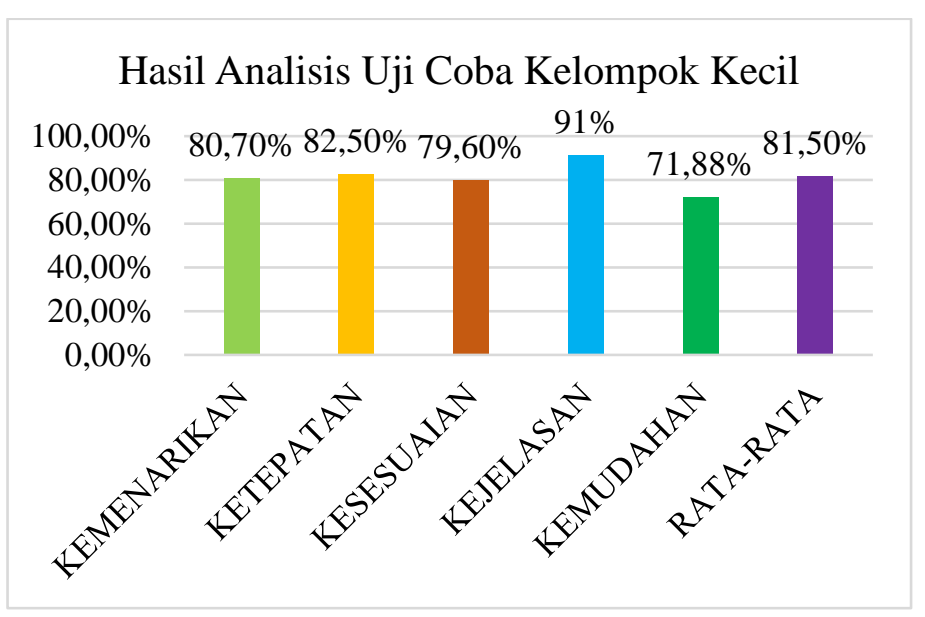

Gambar 6. Diagram Persentase Hasil Analisis Data Uji Coba Kelompok Kecil pada Produk Pengembangan Media Pembelajaran Aplikasi Variasi Permainan Bola Voli 
Dari hasil analisis data yang diperoleh dari uji coba kelompok kecil kelas IV dengan persentase sebesar 81.5\%, hasil tersebut didapatkan berdasarkan aspek-aspek tertentu kemudian dikonversikan berdasarkan tabel klasifikasi kelayakan menunjukan bahwa produk pengembangan media pembelajaran variasi permainan bola voli telah memenuhi kriteria sangat valid dan layak digunakan.

Tabel 10. Hasil Analisis Data Uji Coba Kelompok Besar Pada Kelompok Kerja Guru (KKG) PJOK Sekolah Dasar

\begin{tabular}{cccc}
\hline No & Aspek & Kelayakan & Kategori \\
\hline 1 & Kemenarikan & $77 . \%$ & Sangat Valid \\
2 & Ketepatan & $79.3 \%$ & Sangat Valid \\
3 & Kesesuaian & $82.3 \%$ & Sangat Valid \\
4 & Kejelasan & $87.5 \%$ & Sangat Valid \\
5 & Kemudahan & $76 \%$ & Sangat Valid \\
\hline \multicolumn{2}{l}{ Rata-rata } & $80 \%$ & Sangat Valid \\
\hline
\end{tabular}

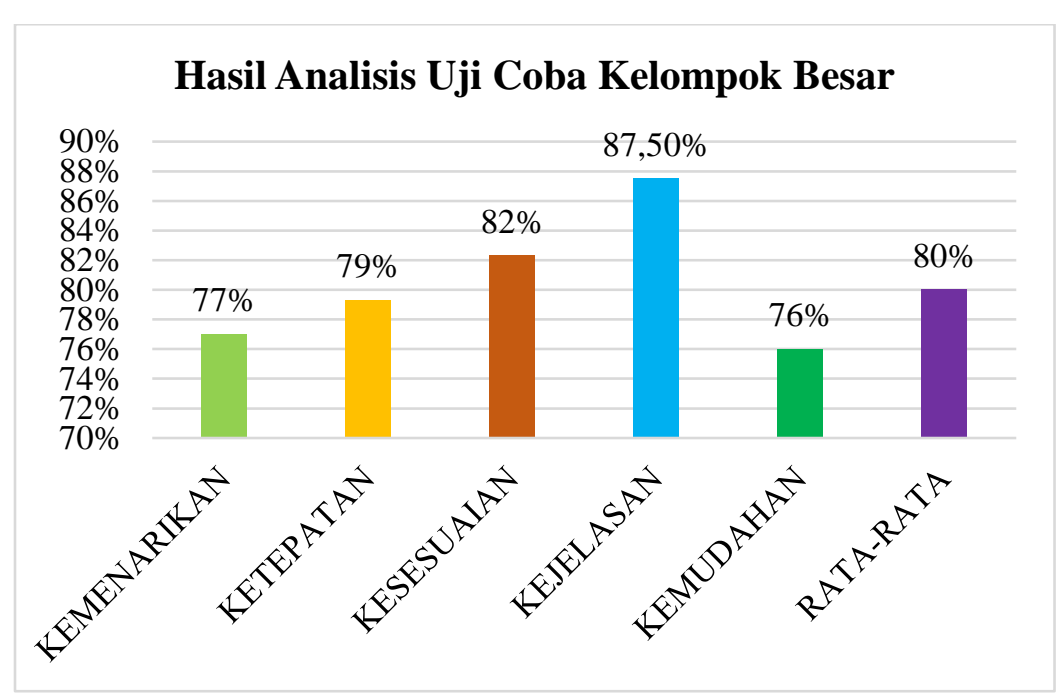

Gambar 7. Diagram Persentase Hasil Analisis Data Uji Coba Kelompok Besar pada Produk Pengembangan Media Pembelajaran Aplikasi Variasi Permainan Bola Voli

Dari hasil analisis data yang diperoleh dari uji coba kelompok besar kelas IV dengan persentase sebesar $80 \%$, hasil tersebut didapatkan berdasarkan aspek-aspek tertentu kemudian dikonversikan berdasarkan tabel klasifikasi kelayakan menunjukan bahwa produk pengembangan media pembelajaran variasi permainan bola voli telah memenuhi kriteria sangat valid dan layak digunakan.

\subsection{Pembahasan}

Peneliti mengembangkan media pembelajaran sebagai sarana dalam proses pembelajaran materi bola voli. Menurut Hidayah. dkk, (2018) Media merupakan sebuah alat maupun sarana untuk mempermudah peserta didik dalam memahami materi yang telah disampaikan oleh guru.

Media yang dikembangkan berupa aplikasi articulate storyline. Articulate storyline adalah media yang dapat digunakan untuk presentasi, aplikasi ini memiliki desain yang sudah disediakan selain itu pengguna dapat mengedit sendiri desain yang akan digunakan dalam aplikasi (Rafmana, 2018). Media aplikasi articulate storyline ini sangat bermanfaat untuk 
proses pembelajaran dan digunakan untuk menyampaikan materi pembelajaran secara menarik, karena dapat menggunakan template yang sudah ada maupun dengan template sesuai dengan selera dan kemampuan penggunanya sendiri. Articulate storyline merupakan salah satu multimedia interaktif yang dapat digunakan sebagai media pembelajaran interaktif, dalam aplikasi articulate storyline menyediakan berbagai macam template yang bisa dipilih untuk materi ajar yang sepenuhnya disajikan secara interaktif, imersif dan menarik, konten yang ada dalam proses pembuatanya yaitu berbentuk slide powerpoint. Hasil penelitian sebelumnya Arwanda, Irianto \& Andriani (2020), dalam jurnalnya menunjukan bahwa pengembangan pembelajaran menggunakan articulate storyline untuk kelas VI memberikan pengaruh yang sangat baik terhadap motivasi dan minat belajar siswa, guru memberikan respon sangat baik terhadap pengembangan tersebut dikarenakan menjadi referensi dan membantu guru dalam menyampaikan pembelajaran yang lebih menarik dan kreatif. Hasil penelitian sebelumnya Akbar \& Hariyanto (2020), dalam jurnalnya menunjukan bahwa pengembangan yang dilakukan dalam bahan ajar yang disampaikan ke siswa melalui media interaktif memberikan peningkatan motivasi, minat, serta hasil belajar siswa yang baik dalam proses pembelajaran. Hasil temuan lain juga menunjukan bahwa pengembangan media interaktif yang diciptakan dalam pembelajaran dapat menjadi salah satu cara menumbuhkan semangat belajar serta menjadi referensi sumber belajar tambahan mata pelajaran PJOK (Rahman, Kurniawan \& Heynoek, 2020)

Media aplikasi articulate storyline ini dibutuhkan untuk menyampaikan materi atau pesan dalam proses pembelajaran bola voli terutama dalam materi variasi permainan bola voli karena sangat jarang materi variasi permainan bola voli disajikan dalam bentuk media dan dikemas secara menarik. Guru KKG PJOK SD di Kecamatan Senduro menyampaikan materi variasi permainan bola voli secara langsung dan belum pernah menggunakan media aplikasi, dalam membantu guru menyampaikan materi variasi permainan bola voli kepada siswa secara menarik maka dibutuhkan media yang tepat untuk menarik minat siswa dalam mempelajari materi variasi permainan bola voli.

Produk hasil pengembangan peneliti berupa media pembelajaran variasi permainan bola voli berbasis aplikasi articulate storyline untuk KKG PJOK SD Kecamatan Senduro Kabupaten Lumajang. Produk yang dikembangkan merupakan produk media sebagai sarana yang digunakan oleh guru dalam proses pembelajaran, penyampaian materi pelajaran kepada siswa yang ringkas secara menarik sehingga bisa menambah minat belajar siswa. Media yang di kembangkan berbasis acrticulate storyline. Articulate storyline berguna dalam proses pembelajaran karena dapat menyampaikan materi dengan mudah. Sejalan dengan Pratama, (2018) yang menyatakan bahwa articulate storyline merupakan media yang digunakan untuk menyampaikan informasi dalam bentuk perangkat lunak. Media produk penelitian dan pengembangan digunakan sebagai sarana untuk menyampaikan sebuah informasi secara efektif dan dan efisien. Dalam rangka mendukung proses pembelajaran diperlukan media yang kreatif dan inovatif guna menarik siswa dalam belajar variasi bola voli.

Dalam meningkatkan suatu kemampuan maupun keterampilan peserta didik pada proses pembelajaran dibutuhkan media pembelajaran yang tepat dan sesuai. Media yang digunakan dalam proses pembelajaran berguna untuk memperjelas penyampaian informasi dan penyajian pesan. Puspitasari, dkk, (2018) media pembelajaran merupakan sarana atau alat yang digunakan dalam proses pembelajaran untuk mencapai tujuan pembelajaran yang efektif dan efisien. Yaitu dengan memanfaatkan media sebagai alat untuk menyampaikan pesan 
ataupun informasi yang dikemas secara menarik sehingga dapat tercapai tujuan pembelajaran. Hasil validasi ahli pembelajaran terkait dengan produk pengembangan media pembelajaran aplikasi variasi permainan bola voli untuk KKG PJOK SD di Kecamatan Senduro Kabupaten Lumajang, diperoleh data berupa saran evaluasi ahli pembelajaran yaitu pembenahan background, tombol, icon, dan animasi agar lebih menarik. Saran dan masukan telah diperbaiki oleh peneliti pada produk pengembangan berupa articulate storyline.

Produk pengembangan media articulate storyline sudah divalidasi oleh ahli media yaitu background di buat lebih menarik dan sumber belajar atau referensi tetap harus disertakan dalam produk yang dibuat. Saran dan masukan dari ahli permainan yaitu menambahkan beberapa orang supaya banyak siswa yang terlibat. Saran dan evaluasi juga disampaikan dari ahli PJOK yaitu penekanan pemahaman KD ke siswa lebih ditujukan. Saran hasil pengisian instrumen evaluasi ahli bola voli yaitu perkembangan aspek variasi gerakanya dan menambah tahapan yang mengarah pada gerakan manipulatif. Bahan ajar yang tepat dan menarik akan diterima oleh siswa dan akan berguna secara efektif. Kegiatan pembelajaran yang menggunakan media sesuai misalnya memanfaatkan articulate storyline pada proses belajar mengajar akan menciptakan suasana yang menyenangkan dan tidak membosankan sehingga proses pembelajaran akan terfokus pada media pembelajaran yang menarik dan membuat aktivitas belajar yang efektif dan efisien.

Berdasarkan hasil uji coba kelompok kecil yang memiliki persentase sebesar 80,2\% dengan kategori sangat valid dan dari presentase uji coba kelompok besar diperoleh hasil $80 \%$ dengan kategori sangat valid. Hal ini menunjukan bahwa pembelajaran menggunakan articulate storyline valid dan dapat digunakan sebagai sarana pada proses pembelajaran variasi permainan bola voli. Hasil produk pengembangan media pembelajaran variasi permainan bola voli menggunakan articulate storyline telah uji validasi dan uji coba serta dilakukan beberapa kali revisi sehingga memiliki beberapa kelebihan (1) Produk dibuat dengan aplikasi articulate storyline yang dapat digunakan secara offline. (2) Berisi tentang bahan ajar berupa video variasi permainan bola voli yang dikemas secara menarik. (3) Permainan yang terdapat pada aplikasi sudah dimodifikasi dengan sarana dan prasarana yang mudah didapat. (4) Produk pengembangan ini dapat digunakan oleh guru sebagai sarana dalam proses pembelajaran online saat ini.

Diharapkan setelah dikembangkannya produk media pembelajaran bola voli akan dapat lebih bervariasi dan lebih modern, sehingga memberikan pengaruh minat peserta didik serta menambah pengetahuan guru dalam bidang teknologi yang bermanfaat untuk pengajar dalam pelaksanaan pembelajaran pendidikan jasmani, olahraga dan kesehatan terutama pembelajaran bola voli kelas IV.

\section{Simpulan}

Maka dari penelitian dan pengembangan ini mendapatkan suatu kesimpulan bahwa produk pengembangan media pembelajaran variasi permainan bola voli berbasis aplikasi articulate storyline yang telah dikembangkan peneliti yang memuat bahan ajar, video permainan bola voli, dan soal evaluasi layak digunakan dalam pembelajaran PJOK pada tingkat sekolah dasar kelas IV. Dengan produk ini nantinya dapat membantu guru dalam menyampaikan materi kepada peserta didik secara menarik. 


\section{Daftar Rujukan}

Akbar, R. A., \& Hariyanto, E. (2020). Pengembangan Bahan Ajar Pencak silat Untuk Siswa Sekolah Dasar. Sport Science and Health, 2(7), 350-356. http://journal2.um.ac.id/index.php/jfik/index

Arwanda, P., Irianto, S., \& Andriani, A. (2020). Pengembangan Media Pembelajaran Articulate Storyline Kurikulum 2013 Berbasis Kompetensi Peserta Didik Abad 21 Tema 7 Kelas Iv Sekolah Dasar. AlMadrasah: Jurnal Pendidikan Madrasah Ibtidaiyah, 4(2), 193. https://doi.org/10.35931/am.v4i2.331

Darnawati, Jamiludin, Batia, L., Irawaty, \& Salim. (2019). Pemberdayaan Guru Melalui Pengembangan Multimedia Pembelajaran Interaktif dengan Aplikasi Articulate Storyline. Jurnal Pengabdian Kepada Masyarakat, 1(1).

Firdaus, R. I., Kurniawan, A. W., \& Heynoek, F. P. (2020). Pengembangan Pembelajaran Kebugaran Jasmani Unsur Kelincahan Berbasis Multimedia Interaktif Di Sma Negeri 1 Turen. Journal Gelanggang Pendidikan Jasmani, 2(2), 99-107.

Hanggara, D., Syafrial, S., \& Ilahi, B. R. (2018). Implementasi Ekstrakurikuler Bola Voli Di Sma N 1, 2 Dan 3 Bengkulu Tengah. Kinestetik: jurnal ilmiah pendidikan jasmani, 2(1), 16-22. https://doi.org/10.33369/jk.v2i1.9182

Hasan, B., \& Hermanto, D. (2019). Pelatihan Pembuatan Media Pembelajaran Berbasis AutoPlay bagi Kelompok Kerja Guru Kecamatan Geger di Kabupaten Bangkalan. Abdihaz: Jurnal Ilmiah Pengabdian pada Masyarakat, 1(2), 53. https://doi.org/10.32663/abdihaz.v1i2.981

Irawan, D., \& Japarianto, E. (2013). Analisa Pengaruh Kualitas Produk Terhadap Loyalitas Melalui Kepuasan Sebagai Variabel Intervening Pada Pelanggan Restoran Por Kee Surabaya. Jurnal Manajemen Pemasaran.

Listyawati, M. (2013). Pengembangan Perangkat Pemebelajaran Ipa Terpadu Di SMP. Journal of Innovative Science Education, 1(1).

Nur, S. M. (2017). Peran Kelompok Kerja Guru ( Kkg ) Dalam Meningkatkan Kompetensi Guru Program Pascasarjana Universitas Halu Oleo. Wakapendik, 2(5), 1-9.

Nurdyansyah, \& Mutala'liah, N. (2018). Pengembangan Bahan Ajar Modul Ilmu Pengetahuan Alambagi Siswa Kelas IV Sekolah Dasar. Universitas Muhammadiyah Sidoarjo, 41(20), 1-15.

Permendikbud. (2018). Kompetensi Inti dan Kompetensi Dasar Kurikulum 2013 Pada Pendidikan Dasar dan Pendidikan Menengah.

Rahman, Z., Kurniawan, A. W., \& Heynoek, F. P. (2020). Pengembangan Pembelajaran Kebugaran Jasmani Unsur Kecepatan Berbasis Multimedia Interaktif. Sport Science and Health, 2(1), 78-92. http://journal2.um.ac.id/index.php/jfik/article/view/11692/5123

Setiawan, I., \& Triyanto, H. (2014). Pengembangan Permainan Tradisonal Gobak Sodor Bola dalam Pembelajaran Penjas pada Siswa SD. jurnal Media Ilmu Keolahragaan Indonesia, 4(1). https://doi.org/10.15294/miki.v4i1.4395

Setyaningsih, S., Rusijono, \& Wahyudi, A. (2020). Pengaruh Penggunaan Media Pembelajaran Interaktif Berbasis Articulate Storyline Terhadap Motivasi Belajar Dan Hasil Belajar Siswa Pada Materi Kerajaan Hindu. Jurnal Pendidikan dan Ilmu Pengetahuan, 20(2), 144-156.

Sitompul, D. (2019). Upaya Meningkatkan Kemampuan Menyusun Rpp Berkarakter Melalui Bimbingan Berkelompok Bagi Guru Negeri Sd 157015 Kebun Pisang Kecamatan Badiri Kabupaten Tapanuli Tengah Pada Semester Genap Tahun Pelajaran 2018/2019. NUSANTARA : Jurnal Ilmu Pengetahuan Sosial, 6(1), 88. https://doi.org/10.31604/jips.v6i1.2019.88-91

Sugiyono. (2015). Metode Penelitian Pendidikan. Bandung: Alfabeta.

Widoyoko, E. P. (2013). Evaluasi Program Pembelajaran. Jurnal Cakrawala Pendidikan, 5(1), 1-16. https://doi.org/10.21831/cp.v5i1.1266

Yasin, A. N., \& Ducha, N. (2017). Kelayakan Teoritis Multimedia Interaktif Berbasis Articulate Storyline Materi Sistem Reproduksi Manusia Kelas Xi SMA. BioEdu, 6(2), 571-579.

Arwanda, P., Irianto, S., \& Andriani, A. (2020). Pengembangan Media Pembelajaran Articulate Storyline Kurikulum 2013 Berbasis Kompetensi Peserta Didik Abad 21 Tema 7 Kelas Iv Sekolah Dasar. AlMadrasah: Jurnal Pendidikan Madrasah Ibtidaiyah, 4(2), 193. https://doi.org/10.35931/am.v4i2.331

Asmadawati. (2014). Perencanaan Pengajaran. Darul Ilmi, 02(01), 1-13. 
Bangun, S. Y. (2016). Pengembangan Pengetahuan Anak Difabel Melalui Pendidikan Jasmani Olahraga dan Outbound. Journal Physical Education, Health and Recreation, 1(1), 70. https://doi.org/10.24114/pjkr.v1i1.4777

Dwijayani, N. M. (2019). Development of circle learning media to improve student learning outcomes. Journal of Physics: Conference Series, 1321(2), 171-187. https://doi.org/10.1088/1742$6596 / 1321 / 2 / 022099$

Ekayani, P. (2017). (2017). Pentingnya Penggunaan Media. (March). Retrieved from https://www.researchgate.net/publication/315105651

Hidayah, P., Fita, M., Untari, A., \& Wardana, M. Y. S. (2018). Pengembangan Media Sepeda ( Sistem Peredaran Darah ) dalam Pembelajaran IPA di Sekolah Dasar. 2(4), 306-310.

Irawan, D., \& Japarianto, E. (2013). Analisa Pengaruh Kualitas Produk Terhadap Loyalitas Melalui Kepuasan Sebagai Variabel Intervening Pada Pelanggan Restoran Por Kee Surabaya. Jurnal Manajemen Pemasaran.

Nur, S. M. (2017). Peran Kelompok Kerja Guru ( Kkg ) Dalam Meningkatkan Kompetensi Guru Program Pascasarjana Universitas Halu Oleo. Wakapendik, 2(5), 1-9.

Permendikbud. (2018). Kompetensi Inti dan Kompetensi Dasar Kurikulum 2013 Pada Pendidikan Dasar dan Pendidikan Menengah.

Pratama, R. A. 2018. Media Pembelajaran Berbasis Articulate Storyline 2 Pada Materi Menggambar Grafik Fungsi di SMP Patra Dharma 2 Balikpapan. Matemati. 7(1), 19-35.

Puspitasari, P., Sari, P., Putri, J., \& Wuryani, W. (2018). Pengaruh Penggunaan Media Pembelajaran terhadap Motivasi Belajar Mahasiswa IKIP Siliwangi. Parole: Jurnal Pendidikan Bahasa Dan Sastra Indonesia, 1(2), 227-232. https://doi.org/http://dx.doi.org/10.22460/p.v1i2p\%25p.243

Rafmana, H., Chotimah, U., \& Alfiandra. (2018). Pengembangan Multimedia Interaktif Berbasis Articulate Storyline untuk Meningkatkan Motivasi Belajar Siswa pada Mata Pelajaran PKN Kelas XI di SMA Sriwijaya Negara Palembang. Jurnal Bhinneka Tunggal Ika, 5, 52-65. https://doi.org/https://doi.org/10.36706/jbti.v5i1.7898

Rahman, Z., Kurniawan, A. W., \& Heynoek, F. P. (2020). Pengembangan Pembelajaran Kebugaran Jasmani Unsur Kecepatan Berbasis Multimedia Interaktif. Sport Science and Health, 2(1), 78-92. http://journal2.um.ac.id/index.php/jfik/article/view/11692/5123

Rahayu, S. (2014). Pengembangan Model Modifikasi Permainan Bola voli Mini “Serpassring” Pembelajaran Penjasorkes Sd Kelas V. Journal of Physical Education and Sports, 3(2).

Saputra, D. G. A., \& Agustina, R. (2014). Pembuatan Media Pembelajaran Interaktif Teknik Dasar Bola Voli Untuk Sekolah Dasar Kelas 4 Pada SDN Bareng 2 Malang. Journal Bimasakti.

Sugiyono. (2015). Metode Penelitian Pendidikan. Bandung: Alfabeta.

Widoyoko, E. P. (2013). Evaluasi Program Pembelajaran. Jurnal Cakrawala Pendidikan, 5(1), 1-16. https://doi.org/10.21831/cp.v5i1.1266

Yusmar, A. (2017). Upaya Peningkatan Teknik Permainan Bola Voli Melalui Modifikasi Permainan Siswa Kelas X Sma Negeri 2 Kampar. JURNAL PAJAR (Pendidikan Dan Pengajaran), 1(1), 143. https://doi.org/10.33578/pjr.v1i1.4381 